\title{
MIT SPOLECZNY KRESÓW WSCHODNICH WE WSPÓLCZESNEJ PRASIE POLSKOJĘZYCZNEJ NA UKRAINIE: ANALIZA ZAWARTOŚCI PRASY
}

\author{
WIKTOR PIETRZAK \\ Uniwersytet Wrocławski, Wrocław — Polska \\ СУСПІЛЬНИЙ МІФ „СХІДНИХ КРЕСІВ” У СУЧАСНИХ \\ ПОЛЬСЬКОМОВНИХ ВИДАННЯХ \\ В УКРАЇНI: АНАЛІЗ ЗМІСТУ \\ ВІКТОР П'ЄТШАК \\ Вроцлавський університет, м. Вроцлав - Польща
}

АНОТАЦІЯ. У статті висвітлено результат аналізу змісту преси з огляду на присутність у ній визначень, що входять у склад міфу „Східних Кресів”. Дослідження статей призвело до визначення особливостей суспільного міфу в сучасних польськомовних виданнях України.

\section{SOCIAL MYTH OF THE EASTERN BORDERLANDS IN MODERN POLISH- LANGUAGE PRESS IN UKRAINE: ANALYSIS OF THE PRESS' CONTENT}

\author{
WIKTOR PIETRZAK \\ University of Wroclaw, Wroclaw — Poland
}

ABSTRACT. The article presents the results of the analysis of the press' content in terms of appearance of notions, which add to the composition of myth of the Eastern Borderlands. The study of press' material has mainly led to defining general characteristics of the social myth in contemporary Polish-language press media published in Ukraine.

$\mathrm{C}$ elem niniejszego artykułu jest prezentacja wyników przeprowadzonej analizy zawartości prasy pod względem występowania w niej warstw znaczeniowych wchodzących w skład mitu Kresów Wschodnich. W pierwszej części przedstawiono założenia teoretyczne pracy, w drugiej — efekty badań ilościowych nad korpusem tekstów prasowych, zaś w trzeciej części zawarto interpretację uzyskanych wyników oraz nakreślono dalsze kierunki badań nad mitem społecznym realizowanym we współczesnych czasopismach polskojęzycznych wydawanych na Ukrainie.

Pojęcie Kresy pierwotnie miało status terminu wojskowego i prawniczego. Od drugiej połowy XIX wieku rozumienie pojęcia uległo wzbogaceniu o wartości symboliczne ${ }^{1}$. Obecnie Kresy definiowane sajako fenomen czy kategoria aksjologiczna, zawierająca bogate warstwy znaczeniowe, które odsyłają do wielopłaszczyznowej historii obecności polskiej na Wschodzie ${ }^{2}$. Współcześni badacze zaznaczają, że termin jest niejednoznaczny (m. in. B. Hadaczek, E. Kasperski, J. Kolbuszewski, M. Janion,

${ }^{1}$ J. Kolbuszewski, Kresy — pojęcie, znaczenia, wartości, [w:] Dziedzictwo kresowe, pod red. A. Burzyńskiej-Kamienieckiej, M. Misiak, J. Kamienieckiego, Wrocław 2013, s. 13.

${ }^{2}$ S. Uliasz, Literatura Kresów - kresy literatury. Fenomen Kresów Wschodnich w literaturze polskiej dwudziestolecia międzywojennego, Rzeszów 1994, s. 13. 
S. Uliasz), jego wyposażenie semantyczne z biegiem czasu ulegało rozszerzaniu o różne sensy, tworząc swoistego rodzaju system wartości uwarunkowany czynnikami historycznymi i kulturowymi ${ }^{3}$. Kresy to także „szczególny rodzaj wspólnoty znakowej, która posługuje się odpowiednimi kodami, rozporządzającymi $<\ldots>$ pewnym zasobem symboli i ustanawiającymi określony repertuar"4. Mając na względzie wielość funkcjonujących definicji pojęcia, na potrzeby niniejszego artykuły przyjęto, że Kresy Wschodnie są kategorią aksjologiczną zawierającą w sobie trzy główne warstwy znaczeniowe: topograficzna, mityczną oraz fantazmat twierdzy (za J. Kolbuszewskim, M. Janion). Warstwa topograficzna odnosi się do ziem wschodnich utraconych przez Polskę w wyniku wydarzeń historycznych (w drugiej połowie XIX wieku warstwa znaczeniowa Kresów Wschodnich rozumiana była jako południowo-wschodnie granice I Rzeczypospolitej, w XX wieku znaczenie topograficzne poszerzono o ziemie północno-wschodnie na linii Wilno - Lwów, które wcześniej za Kresy nie były uznawane). Warstwa mityczna konotuje przestrzeń kulturową ${ }^{5}$, czyli przeobrażenie przestrzeni geograficznej i czasu historycznego w sakralną czasoprzestrzeń kultury zawierającą w sobie m. in. głęboko ukryte sensy oraz bogatą symbolikę narodową ${ }^{6}$. Z kolei fantazmat twierdzy charakteryzowany jest jako pole walki o polską przestrzeń życiową $\mathrm{z}$ nacierającym wrogiem, heroiczna historyczna przeszłość, jedność i nierozerwalność Kresów z Polską jako podstawa szczęśliwości polskiego życia ${ }^{7}$, a także antemurale christianitatis ${ }^{8}$. W przeprowadzonej analizie szczególną uwagę badawczą zwrócono na obecność wyżej wymienionych warstw w konceptualizacji mitu kresowego.

Mit jest istotną formą przekazu na temat wyobrażeń dotyczących przeszłości określonej grupy społecznej. Mając na względzie różnice w jego definiowaniu, w niniejszym artykule wyłącznie przytoczono zestaw cech mitu wspólnych dla różnych dyscyplin badawczych, są to: specyfika czasu mitycznego, sakralizacja rzeczywistości mitycznej, dowodowe funkcjonowanie precedensu, antyracjonalizm, wartościowanie opisywanych wydarzeń oraz związek mitu z rytuałem ${ }^{9}$. Przedstawioną charakterystykę pojęcia należy odnieść do nakreślonego wcześniej zakresu rozumienia pojęcia kresowego.

Jak zaznaczono we wstępie, przedmiotem zainteresowania badawczego jest mit kresowy rozpatrywany w kategorii mitu społecznego. Przez ten ostatni należy rozumieć wiedzę wchodzącą w skład światopoglądu zbiorowego dowolnej grupy, która (wiedza) opisując przeszłe, obecne lub przyszłe stany społecznego świata, nie jest sprawdzana $\mathrm{w}$ sposób intersubiektywny, tylko przyjmowana $\mathrm{w}$ sposób bezpośredni (np. wiara w autorytet tradycji) ${ }^{10}$. Warto podkreślić, że mit społeczny może „wspólistnieć ze świadomością faktów, które mu przeczą”"

${ }^{3}$ J. Kolbuszewski, op. cit., s. 13.

${ }^{4}$ S. Uliasz, op. cit., s. 13.

${ }^{5}$ Określana również jako przestrzeń intelektualna wynikającą z „odpowiedzi uczuć i wyobraźni na podstawowe ludzkie potrzeby”, jednocześnie „,pomijając logikę wykluczenia i sprzeczności”; Yi-Fu Tuan, Przestrzeń i miejsce, Warszawa 1987, s. 130.

${ }^{6} \mathrm{~S}$. Uli as z, Kresy jako przestrzeń kulturowa, [w:] Kresy — pojęcie i rzeczywistość. Zbiór studiów, pod red. K. Handke, Warszawa 1997, s. 132.

${ }^{7}$ J. Kolbuszewski, Kresy jako kategoria aksjologiczna, [w:] op. cit., 119-128.

${ }^{8}$ M. Kosman, O Kresach $w$ historii $i$ legendzie. Studia $i$ szkice z dziejów polskiej granicy wschodniej, Poznań 2011, s. 125-142.

${ }^{9}$ B. Szacka, Czas przeszły, pamięć, mit, Warszawa 2006, s.74-75.

${ }^{10} \mathrm{~W}$. Sitek, Mit spoleczny jako problem teoretyczno-metodologiczny, [w:] Polskie mity polityczne XIX i XX wieku, pod red. W. Wrzesińskiego, t. 10, Wrocław 1996, s. 7.

${ }^{11}$ Tamże, s. 10. 
Treści przekazów medialnych uobecniają poglądy na temat przeszłości w teraźniejszych wypowiedziach. Odwołując się do przeszłości, aktualizują dawne wydarzenia we współczesnym dyskursie prasowym, interpretują je oraz upowszechniają przy użyciu różnych kanałów komunikacji oddziałując na postawy społeczne ${ }^{12}$. Sumując, przez społeczny mitu kresowy należy rozumieć realizowanie w tekście jednej lub wielu z warstw znaczeniowych (kategorii aksjologicznej).

Analize zawartości prasy ${ }^{13}$ przeprowadzono na artykułach pochodzących z „Krynicy” - polskojęzycznego czasopisma ukazującego się od 1994 roku w Kijowie. Badaniem objęto próbę tekstów z 20 numerów kwartalnika, które ukazały się w latach 2008-2012. Z korpusu wyłączono „Numer specjalny. Wszystko o Karcie Polaka" z 2008 roku ze względu na jego charakter odbiegający od typowego numeru. Analizie skupiono się na frekwencji elementów budujących warstwy znaczeniowe mitu wyrażone w sposób eksplicytny w artykułach poświęconych historii (wybór działu poświęconego tematyce historii znajduje uzasadnienie w jej mitotwórczej roli). Następnie przeprowadzono analizę zawartości semantycznej tekstów. Badanie mitu było rozpatrywane w trzech warstwach znaczeniowych (opisanych wcześniej), każdej z nich wyszczególniono elementy semantyczne wchodzące w skład danej warstwy. Poniżej omówiono otrzymane wyniki, uwzględniając kryterium częstości występowania analizowanych elementów w korpusie tekstów ${ }^{14}$.Poszczególne wartości procentowe frekwencji warstw znaczeniowych zostały podane w przypisach dolnych.

Warstwa topograficzna to przede wszystkim operowanie polskimi nazwami geograficznymi, mimo że obecnie funkcjonują ukraińskie ${ }^{15}$, np. Stanisławów Івано-Франківськ, Kijów - Київ, Grzymałowa - Гримайлів. Opisywanym miejscom najczęściej towarzyszy przyporządkowanie postaci, np. Kijów (Київ)rola Józefa Piłsudskiego w wyprawie kijowskiej w 1920 r. (74, 2011), obiektów, np. Nieżyn (Ніжин)-rzadka kolekcja „Polonica” Państwowego Uniwersytetu im. M. Gogola $(76,2012)$, i wydarzeń historycznych z nimi związanymi, np. Wołyń (Волинь) - przypomnienie akcji „Burza” $(63,2009)$. Miejsca przywoływane są także w funkcji symbolu, np. wykorzystywanie licznych konceptualizacji Lwowa (Львів) „исzy miłości ojczyzny i jest nauczycielem ofiary”" toposu Semper Fidelis Poloniae, wykreowanej wielokulturowej mitologii (Lwów jako Arkadia), wizji Lwowa jako Piemontu narodowego odrodzenia (polskiego lub ukraińskiego) czy wizji wiecznego antemurale Christianitatis ${ }^{17 .}$

Warstwa mityczna została zrealizowana w tekście w kilku formach. Najczęściej występują rozmaite konceptualizacje Polaka jako 'dobrodzieja', 'doświadczonego gospodarza', 'krzewiciela cywilizacji i kultury' ${ }^{18}$. Jego obecność gwarantowała danej miejscowości kresowej (w tym także lokalnej społeczności) rozwój oraz szybkie pomnażanie majątku, np.: „To tylko nieliczni Polacy, którzy swoją twórczą pracą przyczynili się do wzbogacenia materialno-duchowego życia mieszkańców" (78,

${ }^{12}$ P. T. Kwiatkowski, Pamięć zbiorowa spoleczeństwa polskiego $w$ okresie transformacji, Warszawa 2008, s. $40-41$.

${ }^{13}$ M. Li s ow ska-Magdzi arz, Analiza zawartości mediów. Przewodnik dla studentów, Kraków 2004.

${ }^{14}$ Przytaczane cytaty pochodzą z kwartalnika „Krynica”; dokładne źródło cytowane frazy będzie oznaczane wyłącznie poprzez podanie numeru, z którego pochodzą oraz roku wydania, np. (66, 2009).

$1592,3 \%$ korpusu tekstów.

${ }^{16}$ S. Ulias z, Literatura Kresów - kresy literatury. Fenomen Kresów Wschodnich w literaturze polskiej dwudziestolecia międzywojennego, op. cit., s. 71.

${ }^{17}$ A. Kozyckyj, Mit wielokulturowości Lwowa na przełomie XX i XXI wieku, [w:] Kresowe dziedzictwo, op. cit. 197-199.

${ }^{18} 61,5 \%$ korpusu tekstów. 
2012), „Ogrody, początkowo zaniedbane, po objęciu zakładów przez Siostry zostały uporządkowane i zagospodarowane tak, ze stanowił poważne zaplecze materialne zakładów" (61, 2008). Przywoływanie postaci Polek i Polaków z jednoczesnym opisem ich zasług i poświęcenia na rzecz danego miejsca jest zjawiskiem częstym, np. w celu zaznaczania wpływu i udziału w rozwijaniu miast czy wsi, np.: „Osiadłszy w scalonym już Grzymałowie na stałe, zasłyną Leonard Piniński jako znakomity gospodarz" $(75,2012)$.

W ponad połowie analizowanych tekstów zawarto wyobrażenia dotyczące niezwykłego bogactwa kultury ${ }^{19}$, a także prężnie funkcjonującego społeczeństwa wielokulturowego żyjącego w zgodzie i poszanowaniu wartości innych narodów, np. „etniczna polifonia” (78, 2012), „działacze swe cele polityczne realizowali we współpracy z innymi nacjami, w tym z Polakami” $(74,2011)$. Odtwarzane znaczenia rzadko były weryfikowane i poddawane obiektywnej interpretacji, jednocześnie w pojawiających się krytycznych ujęciach dominuje polski punkt widzenia, przez co podkreślano bezpodstawne krzywdzenie narodu polskiego, np. „Ludność polską przedstawiano jako „szkodników” „sabotażystów” i „szpiegów”, „umacnianie polonofobii" $(64,2009)$.

Wyobrażenia o arkadyjskich czasach zostały zrealizowane w trzech wymiarach: idealizacja szlacheckości ${ }^{20}, \mathrm{np}$. charakterystyki wybranych postaci z gloryfikacją ich cnót oraz zasług, opisywaniu swojskości oraz słowiańskości ${ }^{21}$, np. w opisach sytuacyjnych, a także upozowanie Kresów na „krainę mlekiem i miodem płynącą”22, o niezwykłym bogactwie przyrody, urodzajności ziem, obfitości plonów, np. „Niebagatelnym elementem tej fortuny był klucz grzymałowski, obejmujący 2 miasteczka oraz około 30 wsi o najlepszej glebie-słynnym podolskim czarnoziemie" $(75,2012)$. Wymienione konceptualizacje nie były częste, pojawiały się głównie w funkcji kontrastu do wydarzeń wojennych (niepowodzeń), prześladowań na tle religijnym lub w wyniku negatywnych działań samych Polaków (np. rozrzutność, niedbałość, życie ponad stan).

Warstwę trzecią zrealizowano w tekstach poprzez pięć elementów znaczeniowych. Najczęstsze konceptualizacje dotyczyły przywoływania heroicznej przeszłości ${ }^{23}$ interpretacja historii nacechowana emocjonalnie, podkreślenie bitności i ofiarności Polaków, gotowości do walk itp., np. „W wyniku walk z przeważającymi siłami ukraińskimi udało się przetrwać niespełna połowie broniących się ośrodków. A więc wobec wszystkich trzech wrogich Polakom czynników-niemieckiego, ukraińskiego i sowieckiego-działania rozproszonych po całym Wołyniu oddziałów własnych nie mogły dać pozytywnych rezultatów.” (63, 2009), „Co więcej, po 14. dniach niezwykle zaciętych ataków tureckich, stosunkowo szczupła załoga zamku trembowelskiego, wprawdzie ostatkiem już sił, ale nadal mężny stawiała opór.” $(75,2012)$. W opisie walk ${ }^{24}$ akcentowano także bratobójczy charakter wojen polsko-ukraińskich. Równie często pojawiają się odwołania do punktów spornych w relacjach polsko-ukraińskich ${ }^{25}$, przywołując wydarzenia, miejsca i obiekty rodzące kontrowersje po obu stronach, np. „Symbolem wzajemnej wrogości stały się walki o Lwów w listopadzie 1918 roku i śmierć tysięcy młodych ludzi po obu stronach, często niedawnych kolegów"

\footnotetext{
$1953,8 \%$ korpusu tekstów.

$2038,5 \%$ korpusu tekstów.

$2123,1 \%$ korpusu tekstów.

$227,7 \%$ korpusu tekstów.

${ }^{23} 69,2 \%$ korpusu tekstów.

${ }^{24} 23,1 \%$ korpusu tekstów.

${ }^{25} 69,2 \%$ korpusu tekstów.
} 
(74, 2011). Mniejszą frekwencją wykazały się prezentacje Polaków jako krzewicieli chrześcijaństwa i obrońców kultury europejskiej ${ }^{26}$, np. „Władze sowieckie przekonały się, ze polska ludność kresowa zachowała swoją głęboką wiarę katolicką i bogate tradycje narodowe. Wiara dawała im siły do przetrwania wszystkich przeciwności" $(64,2009)$, ,Zadanie apostolskie powierzone im przez Założycieli realizowały przede wszystkim w środowisku nauczycielsko-wychowawczym, aby przepoić je w duchu prawdziwie chrześcijańskim” $(61,2008)$, „Wybuch drugiej wojny światowej położył kres temu trwającemu nieprzerwanie od połowy ub. stulecia rozwojowi Uniwersytetu, stanowiącego najdalej wysuniętą na wschód redutę kultury polskiej" $(72,2011)$.

$\mathrm{Z}$ przeprowadzonej analizy wynika, że $\mathrm{w}$ tekstach prasowych poświęconych historii został $\mathrm{w}$ znacznym stopniu zrealizowany mit kresowy. W jego składa wchodzi nie tylko stosowanie polskiego nazewnictwa geograficznego, lecz także przywoływanie miejsc $\mathrm{w}$ celu wykorzystania ich znaczenia symbolicznego $\mathrm{m}$. in. do legitymizacji historii Kresów z polskiego punktu widzenia, prawa do ziemi, współtworzenia mitologii narodowej, kreowania postaw patriotycznych lub oddziaływania na nie, np. wprowadzenia pożądanych modyfikacji.

Do głównych elementów odtwarzających mityczny obraz należą wyobrażenia dotyczące Polaka jako dobrego gospodarza i organizatora życia społecznego, krzewiciela cywilizacji i kultury, który z bogactw wspominanej wielokulturowości czynił siłę napędzającą rozwój społeczności kresowej. W artykułach przywoływane różne postaci, którzy swoją działalnością przyczynili się do rozwoju gospodarczego Kresów, pełnią funkcję wyróżnienia związku z ziemiami Wschodu z jednoczesnym zaznaczeniem wkładu narodu polskiego $\mathrm{w}$ zachodzące procesy postępu cywilizacyjnego, co w sposób pośredni nadaje prawo do posiadania tych ziem.

W warstwie mitycznej zawarto również liczne konceptualizacje Polaków walczących o Kresy, broniących ich przed wrogiem z zewnątrz kraju (przed m. in. Tatarami, Moskalami), a w późniejszym okresie-także przed wrogiem wewnętrznym (np. powstanie Chmielnickiego w latach 1648-1657, działania Ukraińskiej Powstańczej Armii). Przywoływanie konfliktów zbrojnych występuje głównie w funkcji podkreślenia heroicznej przeszłości, waleczności i ofiarności polskiej ludności. To także wyraz przekonania, że Kresy są „wiecznym obozem i polem walki”'27. Próby interpretacji wydarzeń historycznych przyczyniają się z kolei do sakralizacji opisywanych wydarzeń, obiektów oraz postaci ${ }^{28}$.

W tekstach w sposób znaczący została podkreślona rola religii chrześcijańskiej. Osoby duchowne zaprezentowano jako troskliwych opiekunów wspólnoty kościelnej i nieugiętych krzewicieli wiary, w obronie której nie szczędzili własnego życia. Obrazom działalności kościoła katolickiego towarzyszą elementy charakterystyczne dla kultury chrześcijańskiej, najczęściej przytaczane są m. in. ofiarność, niesienie pomocy osobom cierpiącym, poczucie krzywdy i niesprawiedliwości, które spotkały ich podczas posługi na Kresach, np. „W okresie międzywojennym Siostry z narażeniem życia ukrywały w Józefówce wyrzucanych ze swoich mieszkań, szykanowanych i prześladowanych kapłanów, przyjmując ich na mieszkanie" $(62,2008)$.

$\mathrm{Z}$ kolei podejmowana $\mathrm{w}$ tekstach kwestia punktów spornych $\mathrm{w}$ relacjach polsko-ukraińskich dotyczyła wydarzeń przeszłych, związanych głównie z potyczkami zbrojnymi (np. z UPA) i współpracą (np. J. Piłsudskiego z S. Petlura), a także symboliką miejsc i obiektów (np. we Lwowie Cmentarz Obrońców Lwowa)

\footnotetext{
${ }^{26} 46,2 \%$ korpusu tekstów.

${ }^{27}$ S. Ulias z, op. cit., s. 107.

${ }^{28}$ B. Szacka, op. cit., s. 69.
} 
ma znaczenie sakralne, co potwierdzają konceptualizacje odnoszące się do Cmentarza - udział dzieci i młodzieży w walkach o miasto wzbudza podziw i szacunek, śmierć poniesiona na placu boju w swoisty sposób kanonizuje poległych, ponadto obrazy zabarwione są tonacją wzniosłą i patetyczną, podkreślając doniosłe znaczenie narodowe miejsca i wydarzenia, do którego ono odsyła) ${ }^{29}$.

W większości tekstów, wchodzących w skład korpusu badawczego, nie uwzględniono lub pominięto negatywne oddziaływanie władz polskich na ludność ukraińską (np. w tworzonych obrazach wyidealizowanego społeczeństwa kresowego jako wielokulturowego nie wspominano o polskiej polityce wobec ludności ukraińskiej). Najprawdopodobniej takie działanie wynika z obawy przed krytyczną refleksją nad mitem kresowym-odróżnieniem faktów od wyobrażeń na ich temat z którą bezpośrednio wiąże się z desakralizacja mitu, pozbawienie go świętości. Jednak należy zaznaczyć, że w korpusie nieliczne teksty zawierają krytyczne interpretacje przeszłości, próby obiektywizacji stosunków polsko-ukraińskich, np. przedstawiono opinie polskich i ukraińskich historyków na temat stosunków polskoukraińskich w okresie II Rzeczypospolitej — w artykule zawarto genezę konfliktów między narodami, omówiono czynniki wpływające na bieg tych wydarzeń, a także określono ich historyczne znaczenie $(59,2008)$.

W analizowanej warstwie znaczeniowej odnotowano obecność czasu mitycznego, wyrażającego sięw tworzeniu pozorów „dziania się tu i teraz” kresowej rzeczywistości z jednoczesnym przypominaniem o niemożliwości powrotu do przedrozbiorowej i przedwojennej przeszłości. Kreowanie specyficznej czasoprzestrzeni wynika z potrzeby kompensacji, która jest wyrazem niepogodzenia się z utraconym posiadaniem, wyrazem niezgody na nieodwracalne wydarzenia historyczne ${ }^{30}$.

Rozgrywające się wydarzenia w czasie mitycznym prezentowały polski punkt widzenia na geografię i historię ziem wschodnich, nie zawsze wykazując ścisły związek z faktami historycznymi, co wiąże się z rolą mitu jaką pełni on dla danej zbiorowości — ważna jest treść mitu, a jego prawdy nie podlegają weryfikacji ${ }^{31}$.

Związek mitu zrytuałem zostaje znajduje wyraz w formie artykułów rocznicowych lub jubileuszowych, w których przywoływane są określone historyczne wydarzenia (np. akcja „Burza” na Wołyniu) i obiekty (np. dawny Uniwersytet im. J. Kazimierza we Lwowie), przypominane postaci (np. S. Petlura, J. Piłsudski, gen. A. Listowski, gen. T. Bór-Komorowski). W tym miejscu należy zaznaczyć, że kalendarz rocznic to swego rodzaju narzędzie organizowania zbiorowego pamiętania o wydarzeniach minionych, które są istotne dla kultury narodowej ze względu na pełnione funkcje $\mathrm{m}$. in. porządkowanie i stabilizowanie życia zbiorowości, integrowanie jej, określenie rytmu i powtarzalności czynności, odróżnia czas sakralny od czasu zwykłego ${ }^{32}$.

Mity funkcjonują w powszechnym obiegu są swoistego rodzaju środkiem przekazu uproszczonych informacji, uzupełnieniem zorientowanego aksjologicznie systemu opisu świata, a także zbiorem określonych reakcji, wyzwalanych pod wpływem emocji. Bezwzględna wiara w ich prawdziwość i adekwatność proponowanych wzorów wyzwala siłę, która oddziałuje na kształt rzeczywistości ${ }^{33}$. Polskie mity kresowe pełniły różne funkcje: programowały wzory postępowania

${ }^{29}$ S. U1iasz, op. cit. s. 102-111.

${ }^{30}$ E. Kaspers ki, Teoria i literatura w sytuacji ponowoczesności, [w:] Literatura i różnorodność. Kresy i pogranicza, pod red. E. Biernacki ej, Warszawa 1996, s. 107.

${ }^{31}$ B. Szacka, op. cit., s. 90-92.

${ }^{32}$ P. T. Kwiatkowski, op. cit., s. 283-284.

${ }^{33}$ P. Wawrzyński, Mit kulturowy jako czynnik ksztattujacy stosunki międzynarodowe, Toruń 2011, s. 52-58. 
(zarówno codzienne, jak i dążenia niepodległościowe), utwierdzały w przekonaniu o polonizacji Kresów, integrowały polską społeczność kresową, legitymizowały polską państwowość, kompensowały niepowodzenia ${ }^{34}$.

Można stwierdzić, że mit kresowy jest obecny w analizowanej zawartości prasy mniejszości polskiej na Ukrainie. Jego realizacja była obecna na poziomie trzech warstw znaczeniowych. W tym miejscu warto zaznaczyć, że przyjętą na potrzeby analizy definicję mitu kresowego (za J. Kolbuszewskim, M. Janion) rozumianego jako kategoria aksjologiczna zawierającą w sobie trzy główne warstwy znaczeniowe: topograficzna, mityczną oraz fantazmat twierdzy w przyszłości należałoby wzbogacić o mity wspótistniejące, mające charakter podrzędny i uzupełniający ${ }^{35}$. Należy dodać, że mity są swoistym „odbiciem idei, wartości, tęsknoty współcześnie nurtującej ludzi”’36, wyrażając tym samym współczesną świadomość narodową społeczeństwa.

Artykul opracowano na podstawie wyników badań, które zostanq opublikowane w tomie Dziedzictwo Kresów: kultura - narody - wyznania pod redakcja I. Kozimali, A. Królikowskiej, B. Topij-Stempińskiej pod tytułem Mit Kresów Wschodnich we współczesnej prasie polskojęzycznej na Ukrainie. Analiza zawartości kwartalnika „Krynica”. Niniejszy tekst stanowi wersję rozszerzonq i uzupetniona.

\footnotetext{
${ }^{34}$ B. Hadaczek, Kresy w literaturze polskiej. Studia i szkice, Gorzów Wielkopolski 1999, s. 28.

${ }^{35}$ E. Kasperski, op. cit.

${ }^{36}$ Uwaga H. Samsonowicza przytoczona przez B. Szacka, op. cit., s. 89.
} 